\title{
International Series: Integration of community pharmacy in primary health care Primary health care policy and vision for community pharmacy and pharmacists in Estonia
}

\author{
Kristiina SEPP (D), Anita TUULA, Veera BOBROVA (D), Daisy VOLMER (iD).
}

Published online: 3-May-2021

\begin{abstract}
Estonia, with a population of 1.3 million, is the smallest country in the three Baltic States. As a post-soviet country, Estonia over the past 30 years has built up a new health care system, including the pharmaceutical sector. The GDP allocated to cover health care costs is significantly lower in Estonia compared to the EU average. Despite this, Estonia has excelled in the development of digital e-services in healthcare at both the domestic and international levels. The development and integration of the Estonian community pharmacy sector into primary health care has been influenced and affected by the liberalization within pharmaceutical policy and the lack of cooperation with the rest of the health care sector. Community pharmacy ownership and location matters have been prevalent. The promotion of the pharmacy services has mostly taken place on the basis of a professional initiative, as cooperation with the state has not been active. Possibly the professional fragmentation of the pharmacy sector may have played a negative role. The community pharmacy network in Estonia, especially in cities, enables fast and convenient access to the pharmacy services. Community Pharmacy Service Quality Guidelines support the harmonization of the provided services and patient-centered concept to enhance the patient role and involvement in their care. In recent years, community pharmacies in Estonia have also offered various extended services that are more or less integrated with the primary health care system. New developments may be affected by frequent changes in legislation and a shortage of professional staff in community pharmacies. The ownership reform of pharmacies in 2020 has so far not had a significant impact on the operation of pharmacies or the quality of services provided.
\end{abstract}

Keywords

Pharmacies; Primary Health Care; Delivery of Health Care, Integrated; Ambulatory Care; Community Health Services; Pharmacists; Community Pharmacy Services; Professional Practice; Estonia

\section{INTRODUCTION}

Estonia regained its independence from Russia in 1991 and became a member of the European Union (EU) in $2004 .^{1}$ The population of Estonia is 1,328,976 (2020), of which $19.8 \%$ are 65 years and older. ${ }^{2,3}$ According to the Human Development Index, the country is ranked as very high. ${ }^{4}$ Citizens of Estonia are one of the world's most digitallyadvanced societies. ${ }^{5-7}$ In Estonia, the share of GDP allocated for health care is lower than the EU average $-6.74 \%$ and $9.85 \%$, respectively. ${ }^{3}$ In Estonia, the share of public expenditure for health care is also lower (13\%) than in the EU $(15 \%) .^{8}$ In recent years the average life expectancy has increased for women to 82.8 years and for men to 74.4 years. $^{8}$ In 2019 healthy life years in men were 54.1 and women 57.6, respectively. ${ }^{9}$ Thus, people in Estonia live longer, but are not healthier. ${ }^{10}$

\section{Structure of healthcare system}

The Estonian healthcare system is led by the Ministry of Social Affairs (MoSA) and its agencies. ${ }^{11,12}$ Healthcare is funded publicly from a mandatory social tax and from the state budget. The Estonian Health Insurance Fund (EHIF) manages the national health insurance scheme that covers approximately $95 \%$ of the population. While the EHIF covers around $2 / 3$ of health expenditure, the remaining $1 / 3$

\footnotetext{
Kristiina SEPP. MSc. Junior Lecturer. University of Tartu. Tartu (Estonia).kristiina.sepp@ut.ee

Anita TUULA. MSc. Community Pharmacist. Ringtee Selver Südameapteek. Tartu (Estonia). anita.tuula@ut.ee Veera BOBROVA. MSc. Junior Lecturer. University of Tartu. Tartu (Estonia).veera.bobrova@gmail.com Daisy VOLMER. PhD. Associate Professor. University of Tartu. Tartu (Estonia). daisy.volmer@ut.ee
}

comes from municipalities and private expenditure (approximately quarter of all health expenditure, mainly in the form of co-payments for medicines and dental care). ${ }^{13}$ As the Estonian population is aging, the continuous decrease of working age population threatens the financial sustainability of the health care system since health insurance payments are made by the majority of the working age population. ${ }^{14}$ In March 2021 MoSA introduced proposals for ensuring the sustainability of financing of the health care system including expansion of insurance coverage and reduction of patient waiting lists. ${ }^{8}$

Medical care in Estonia is divided into three levels: primary or family medical service, specialized medical care, and nursing care. ${ }^{5}$ The central role is performed by a general medical practitioner (GP), acting as the first level of contact and they coordinate, manage, and authorizes almost all health services provided to the patient. ${ }^{15}$ From March 2016, family nurses, who have undergone 120 hours clinical pharmacology training, can renew repeat prescriptions for chronic patients. ${ }^{16}$ Furthermore, nurses can have independent appointments to provide vaccinations, health promotion and care for patients with chronic illnesses. In recent years, primary health care reform has been implemented, concentrating services in health centers. In addition to GPs, midwifery, physiotherapy and home care services are provided. ${ }^{15}$ In some cases, the actual data on numbers is not available, the premises in healthcare centers are rented to community pharmacists, but they operate as a self-financing separate unit.

As community pharmacy service is not legally defined as a healthcare service nor a basic primary health care service in Estonia, community pharmacies do not constitute an 


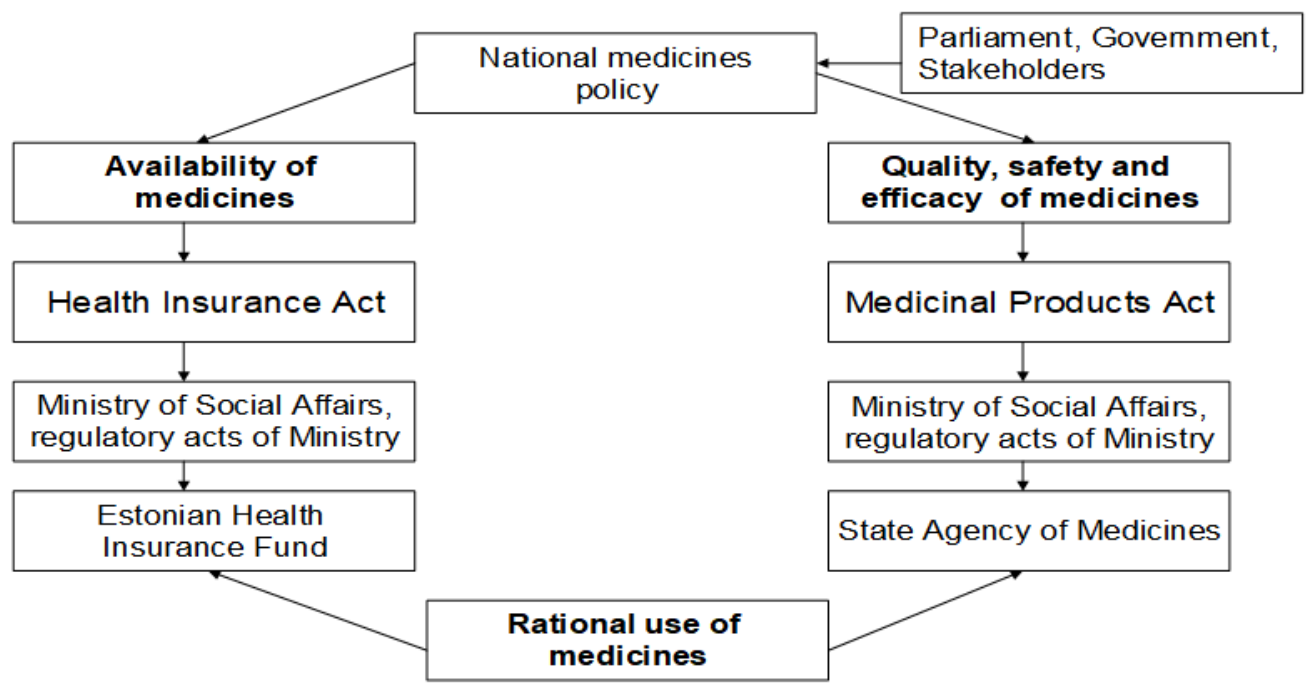

Figure 1. Pharmaceutical policy structure in Estonia. ${ }^{11}$

integral part in primary health care centers and are not involved in the provision of primary healthcare services. ${ }^{17}$

\section{E-health}

Estonia has been outstanding with innovative e-solutions in healthcare. Patient health records are stored electronically in a nationwide e-Health Record system, which allows integrating data from different healthcare providers and create a common record accessible online by patients and health care specialists. Community pharmacists can only retrieve part of the information needed for the dispensing of medicines which is received from the digital prescription database. The e-prescription system is a centralized paperless system for issuing and handling prescriptions. Community pharmacists can access prescription information (name of the active ingredient, pharmaceutical formulation, instructions for use and disease diagnose code) by entering a patient's ID code to the system. The eprescription system was implemented in January 2010, and only 15 months after its launch, around $80 \%$ of prescriptions were e-prescribed. ${ }^{18}$ Currently, $99 \%$ of prescriptions are issued electronically. ${ }^{19}$

Estonia has been a leading partner in development of crossborder exchange of the digital prescription data project started in 2017 involving $23 \mathrm{EU}$ countries. ${ }^{20}$ In January 2019, Finnish patients were the first in the world to purchase their medicines with digital prescriptions prescribed by Finnish physicians at community pharmacies in Estonia. Estonian patients in Finland have been able to use the same opportunity since June 2020. In 2019, 6,847
Finnish e-prescriptions were dispensed in Estonia. A patient with a cross-border digital prescription must pay the full price for the medicine prescribed and after reclaim the amount paid for the medicine from insurer at the home country. ${ }^{21}$ Thus, launching of the cross-border electronic prescriptions exchange could be seen as a historical milestone ensuring continuity of care for people across the EU.

\section{Pharmaceutical policy}

In Estonia radical reforms started with regaining independence in 1991 that constituted a new political and social order. At the same time a number of reforms also took place in the pharmaceutical sector. It was necessary to have pharmaceutical regulatory authorities, create a legislative framework, organize a reimbursement system for medicines and reorganize the pharmacy sector. ${ }^{22}$ The regulatory framework for the pharmaceutical sector is based on the Medicinal Products Act, (first adopted in 1996) and the Health Insurance Act. ${ }^{23,24}$

The primary state stakeholders in Estonian pharmaceutical sector are the MOSA, the State Agency of Medicines (SAM) and the EHIF (Figure 1). There are nine professional organizations (Table 1) operating in 2021, which has rather fragmented the activities of the pharmaceutical sector and hindered constructive collaboration with the state as there is no single umbrella organization. Four out of nine professional organizations in the pharmacy sector represent community pharmacies or pharmacists.

\begin{tabular}{|c|c|c|}
\hline & Pharmacists & Assistant pharmacists \\
\hline Number of professionals & $\begin{array}{l}803(26.03 .2021), 40 \% \text { of total community pharmacy } \\
\text { workforce }\end{array}$ & $\begin{array}{l}652(26.03 .2021), 34 \% \text { of total community pharmacy } \\
\text { workforce }\end{array}$ \\
\hline Education & Master Degree at the University of Tartu (5 years) & $\begin{array}{l}\text { Professional higher education at the Tallinn Health } \\
\text { Care College ( } 3 \text { years) }\end{array}$ \\
\hline Professional roles & $\begin{array}{l}\text { Pharmacy owner, pharmacy manager, responsible } \\
\text { pharmacist, pharmacist }\end{array}$ & $\begin{array}{l}\text { Assistant pharmacist, pharmacy manager only in the } \\
\text { structural unit of the main pharmacy }\end{array}$ \\
\hline \multicolumn{3}{|c|}{$\begin{array}{l}\text { Main professional roles of both professions are organization and provision of high-quality pharmaceutical care: dispensing and counselling } \\
\text { of prescription and OTC medicines; compounding of extemporaneous medicines; point of care testing (e.g. blood pressure measurement, } \\
\text { cholesterol); disease prevention and health education; reporting of adverse drug reaction; provision of extended services (mostly } \\
\text { pharmacists). }\end{array}$} \\
\hline
\end{tabular}


Despite the diversity of professional organizations, in March 2021, a vision document for the activities of community and hospital pharmacies to 2030 was presented to the public. In addition to seven professional organizations (Association of Pharmaceutical Manufacturers in Estonia and Association of Pharmaceutical Wholesalers in Estonia were excluded), two higher education institutions providing pharmaceutical education in Estonia (University of Tartu and Tallinn Healthcare College) were also involved. The vision document covers three objectives: the establishment of an integrated pharmaceutical education system involving undergraduate and continuous professional development; innovation, development, and operation of the pharmacy sector; more effective involvement and contribution of the pharmacy sector as an equal partner in the healthcare system. ${ }^{25}$

In 2020, the MoSA together with different stakeholders commenced to update the Pharmaceutical Policy document (the previous version dates from 2013) based on the principles of the Pharmaceutical Strategy for Europe to address patients' therapeutic needs. ${ }^{26}$ The main principles in the development of pharmaceutical policy in Estonia are to ensure consistent availability of effective, high-quality and safe medicines and to support the extension of people's healthy life expectancy and the improvement of patients' quality of life.

Approximately $20 \%$ of the healthcare costs paid by the EHIF are allocated to reimbursement of prescription medicines. ${ }^{27}$ The price of medicines in the outpatient setting includes price stated by manufacturer, a fixed wholesale mark-up (on average $3.92 \%$ in 2019), a fixed retail mark-up (on average $13.19 \%$ in 2019) and $9 \%$ of VAT. ${ }^{28,29}$

Medicinal products which are included in the list of reimbursed pharmaceuticals (based on the price agreement between manufacturer and EHIF) are compensated based on the reference price of the medicine and the patient's diagnosis. The process of price setting begins with the price being agreed between government and manufacturer. A reference price is then set based on the second cheapest medicine containing the same active ingredient and having the same formulation. Based on the reference price and diagnosis the price of medicine is discounted for the patient according to the discount rates: $100 \%, 90 \%, 75 \%$ and $50 \%$. For compensated medications, patients pay the deductible of 2.5 euros, the amount exceeding the reference price or agreed price and the remaining percentage.

In Estonia, out-of-pocket payments make up $23.6 \%$ of health expenditure, which is above the EU average of 15.8 $\%$. Pharmaceuticals and dental care comprise the largest part of out-of-pocket spending. ${ }^{30-32}$ However, during the last years, the market share of generic medicines has increased and in 2018, generic medicines accounted for $76 \%$ of prescription medicines packages dispensed at community pharmacies. ${ }^{33}$

In 2018 additional medicines reimbursement system was launched, to lower out-of-pocket payments. Patients who pay at least EUR 100 per the calendar year for reimbursed medicines receive extra compensation. ${ }^{30,34}$ This is a positive step towards a people-centered approach that makes medicines affordable, leads to higher adherence. Based on the legislation, pharmacists are obliged to offer the patient both OTC and prescription medicines at the cheapest price as a first choice. ${ }^{35}$ Thus, the pharmacist has an important role in ensuring effective and affordable drug treatment.

\section{COMMUNITY PHARMACIES}

Reorganization of the community pharmacy sector in Estonia began immediately after independence in 1991. The opening, operation and management of community pharmacies are regulated by the Medicinal Products Act, entered into force for the first time in 1996 . $^{23}$ From 19962015 the ownership of community pharmacies was not limited to the pharmacy profession. However, from 20062013 there were applied restrictions applied to the opening or location of new entities. The "liberal" ownership system led to the rapid growth of community pharmacies, from about 250 in 1993 to 496 (352 main pharmacies with 146 structural units) by $2020 .^{36}$ The number of community pharmacies increased in urban areas and remained the same or even decreased in rural regions. ${ }^{37}$ In the largest two cities three community pharmacies are open $24 / 7 .^{37}$ Since 2013 , online-pharmacies have operated as subsidiary units of community pharmacies and at the beginning of 2021 four online pharmacies provided services in Estonia. ${ }^{38}$

Financial operation of community pharmacies is based on fixed mark-ups of medicines (on average 14\%) [39]. The total turnover of community pharmacies in 2019 was 413 million euros (share of medicines $72 \%$ ) and it increased by $5.6 \%$ compared to the previous year. The turnover of medicines includes turnover of over-the-counter, prescription and veterinary medicines. The average annual total turnover of a community pharmacy was 0.85 million euros and $88 \%$ medicines sales are made in pharmacies located in cities. ${ }^{36}$ As the mark-up for medicines have remained unchanged since 2005 , pharmacies have had to find additional ways to increase their income.

Since the second half of the 1990's, both vertical (the retail and wholesale distribution of medicines is linked through the same owner) and horizontal (pharmacy chains) integration of pharmacy sector has commenced. One domestic and three foreign pharmacy chains were in operation in 2020 in Estonia. In order to increase the professional independence of pharmacists as healthcare professionals and to reduce the impact of horizontal and vertical integration to professional activities, the MoSA enacted the ownership reform from the 1st of April 2015, allowing only pharmacists to be the owner of a community pharmacy. ${ }^{23}$ Of the professional organizations, Estonian Pharmacists Association (uniting about $10 \%$ of the pharmacy owners) and Estonian Pharmacists Chamber (about 100 member pharmacists) were the main drivers to the ownership reform. In 2013, the Supreme Court on the request of the Chancellor of Justice prohibited community pharmacy establishment restrictions as it limited the freedom of entrepreneurship and thus is in conflict with the Estonian Constitution. ${ }^{40}$ In 2015 new ownership rules, restrictions for opening branch pharmacies (subsidiary units of main community pharmacies with reduced 
requirements on operation of pharmacy) in the cities with more than 4000 inhabitants and prohibition of vertical integration were approved with a transition period of five years $2015-2020 .^{41}$ According to the ownership regulation, only the pharmacist with at least three years of working experience could be the sole owner of the community pharmacy or hold at least $51 \%$ of the shares in maximum of four pharmacies. $^{23}$ In January 1, 2020, there were 181 community pharmacies operating in accordance with new ownership requirements. Thus, more than $75 \%$ of the community pharmacies ownerships had to be adjusted according to the new regulations. ${ }^{42}$ Pharmacists were invited and encouraged by the government to own existing community pharmacies or to establish new ones. On the other hand, the possibilities for financing the purchase of a pharmacy were unclear and it was uncertain whether the reform would enter into force at all. In December 2019, the pharmacy chains submitted a request to the Parliament of Estonia to reverse the legislation change. ${ }^{43}$ After heated debates it was decided to continue with the announced reform and in the $1^{\text {st }}$ of April 2020, that only pharmacists became owners of community pharmacies. Although the ownership reform was expected to reduce the number of pharmacies in larger cities, it remained nearly the same, as most of the pharmacies continued to operate after the legislation changed. The majority of the new owners signed a franchise agreement with the former pharmacy chains to use their brand and to receive support in managing the pharmacy and recruiting staff. For the customer, nothing changed in the appearance of pharmacies or in the provision of services. In March 2021, the Supreme Court of Estonia stated that according to the Medicinal Products Act, the formal control of ownership was not sufficient for granting an activity license to a pharmacy, but it must be determined that the pharmacist had a controlling influence over the pharmacy. ${ }^{44}$

As the time of changes coincided with the COVID-19 pandemic in March-April 2020, it is too early to make conclusions of the ownership reform outcomes. It must be noted that despite major changes in the pharmacy system, the pharmacy service was available to patients throughout the pandemic, and pharmacists worked on the frontline together with other healthcare professionals, to ensure the health of patients. ${ }^{42}$

\section{Community pharmacy staff}

In 2019, on average 2-5 employees work in a community pharmacy with equal number of pharmacists and assistant pharmacists (Table 1). ${ }^{36}$ In addition, customer service specialists and other support staff form $26 \%$ of the community pharmacy workforce and do not need any special training. Customer service specialists are responsible for dealing with other goods sold in pharmacy (not medicines). It is common for pharmacy students to work as customer service specialists during their studies. ${ }^{45}$ Community pharmacies have a monopoly on the sale of prescription and OTC medicines in Estonia.

\section{PHARMACY SERVICES}

Pharmacy services in Estonia have historically focused on traditional services such as dispensing and compounding of medicines, and counselling on medication use (Figure 2). In recent years, the development of Community Pharmacy Service Quality Guidelines (CPSQG) has initiated a structured development and standardization of pharmacy services in order to expand pharmacists' role in the primary health care system.

CPSQG were initially published in 2012 and updated in 2016 and 2021 as a profession driven initiative in collaboration with pharmacy professional organizations, representatives of the SAM, the University of Tartu and Tallinn Health Care College. The aim of the CPSQG is to formulate the principles of contemporary and quality community pharmacy services, and to define clear criteria for service evaluation. CPSQG are divided into ten chapters, of which three describe counselling of prescription and non-prescription medicines, self-treatment; health promotion; preparation of medicines and provision of extended services; two chapters are devoted to handling of medicines and

\section{Community pharmacy services in Estonia}

\section{Traditional services}

Dispensing and counseling of prescription
and OTC medicines

Counseling of self care

Dispensing and counseling of food supplements, herbals, vitamins

Compounding

\section{Extended services}

Point-of-care testing (blood pressure, cholesterol, etc.)

Pharmacist-led medicine use review

Vaccination (influenza virus, tick-borne encephalitis)

Harm reduction (HIV), smoking cessation

Figure 2. Description of community pharmacy services in Estonia 


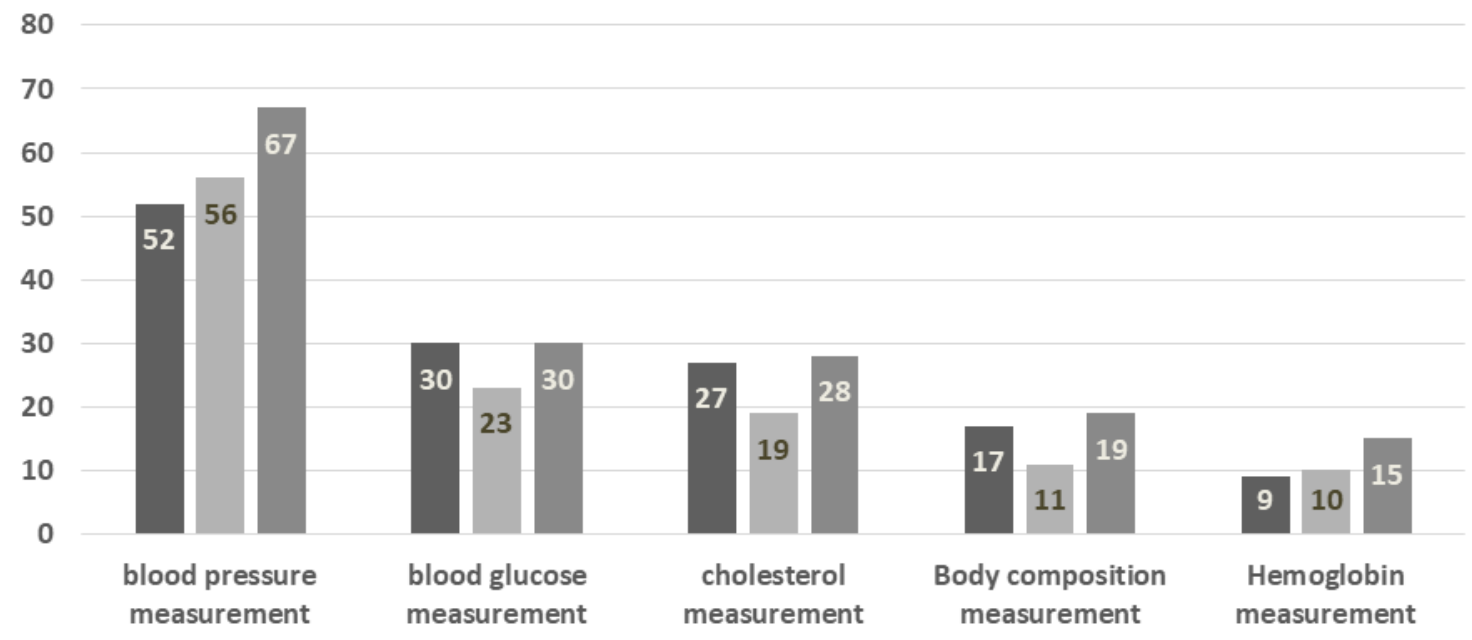

口2014 $2016 \square 2019$

Figure 3. Number of community pharmacies: Provision of the most common point-of care testing services in community pharmacies based on the CPSQG self-assessment 2014-19 (\%).

pharmacy premises; another two to pharmacy management and communication; and the rest of three chapters to continuing professional development of pharmacists, professional legislation and ethics. CPSQG has more than 100 quality indicators and according to the Donabedian classification, the QGCPS indicators are mostly structure or process-based. ${ }^{47}$ There have been three CPSQG based voluntary self-evaluations by community pharmacists in 2014, 2016 and 2019 and on average 40\% community pharmacies in Estonia participated. The results demonstrate improvement in the quality of self-medication counselling, however medication safety aspects did not change significantly. ${ }^{48}$

\section{Expanding the role of community pharmacies}

In recent years, due to the high workload of physicians and nurses, increase in polypharmacy and chronic diseases, and population aging, new possibilities of extended services have been explored by professional pharmacy organizations, active community pharmacists and pharmacy owners, academics and in some cases by government agencies to meet patients' needs and integrate pharmacy services into primary health care. Long opening hours and accessibility of community pharmacy have contributed to provision of vaccination and harm reduction services in community pharmacies. Recently, pharmacistled medication review and smoking cessation services have been successfully piloted. Community pharmacies have also been participating in public health campaigns to increase health awareness. ${ }^{49-51}$ Despite patient satisfaction, extended pharmacy services have gained little national appreciation, and some are even portrayed as controversial by policy makers and other healthcare professionals. ${ }^{52,53}$ Currently, pharmacy extended services are mainly provided without remuneration or for out-of-pocket payments by the patient.

\section{Point-of-care testing}

In Estonian community pharmacies, pharmacists are providing many point-of-care tests including blood pressure, blood glucose, cholesterol, hemoglobin, triglycerides, bone density and body composition measurements (Figure 3). ${ }^{48}$ In some pharmacies, point-ofcare tests of vitamin D levels and Lyme disease are available. The services are either free or funded from outof-pocket payments by patients from 0.5 EUR to 16 EUR depending on the test and the pharmacy. As point-of-care testing in pharmacies is not considered a healthcare service, patients with concerning results are directed to their GP for confirmatory testing. ${ }^{54-56}$ In 2019, 21 community pharmacies in Estonia participated in a diabetes risk-assessment campaign, where more than 600 patients without diabetes diagnosis received blood glucose testing and counselling. Around $20 \%$ of participants had higher than normal blood glucose levels measured for the first time and almost $25 \%$ were considered having high or very high risk of developing diabetes in 10 years. ${ }^{57}$

\section{Medication use review service}

To address population aging and increase in polypharmacy, community pharmacists in Estonia have explored possibilities of standardizing and implementing a medication review service (MUR). In 2019-2020, the first MUR service was piloted (Figure 4). The aim of the service was to educate patients about their medicines and diseases, thus attempting to improve patients' medication adherence and effectiveness of medicines use. In the pilot, 67 mostly elderly polypharmacy patients received MUR in five community pharmacies. Pharmacists did not receive any funding for the service during the pilot. ${ }^{58}$ Patients' and GPs' feedback was mainly positive. Many patients confirmed MUR supported understanding their medication schemes, and they found gained knowledge and the pharmacist's advice highly valuable. ${ }^{52}$ Discussions are ensuing with different stakeholders on service funding, training requirements and access to patient health records necessary for the service. The pilot project has already initiated the first clinical pharmacy e-learning course at the University of Tartu with the aim of training community pharmacists to provide the MUR service. ${ }^{59}$ The goal would 


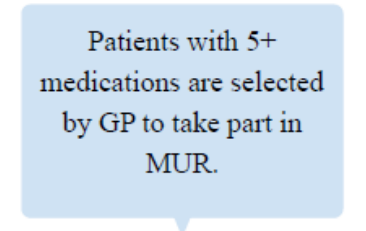

Patient visiting their GP

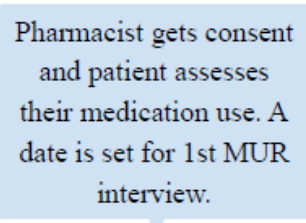

Patient education about their medicines and

diseases, repeating

medicine use details and detecting problems.
Main focus on still existing DRPs.

Compiling correct medication list

isiting their GP

lst meeting at the pharmacy lst MUR interview at the pharmacy
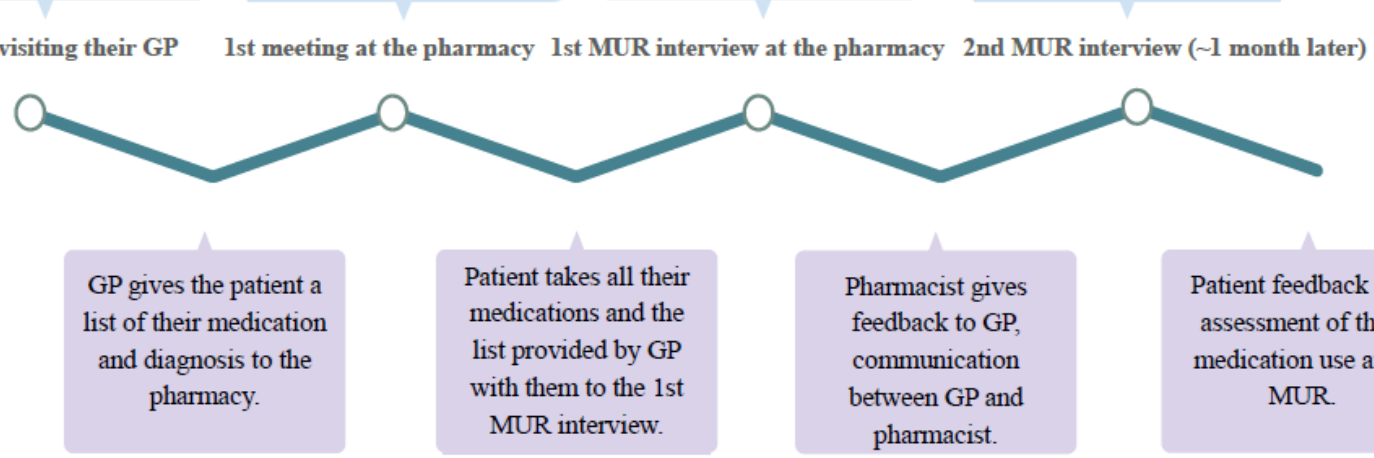

Figure 4. Description of the MUR service provided during the pilot at community pharmacies in Estonia.

be to routinely provide medication reviews by a team of collaborating healthcare workers, each with different expertise. In Estonia GPs regard the development of the MUR service as an opportunity for potential collaboration with pharmacists. $^{52}$

\section{Vaccination}

In Estonia, vaccination coverage for seasonal influenza virus in the past has been very poor particularly in the older age groups. ${ }^{61}$ In autumn 2018, the flu vaccination service was first introduced in 15 community pharmacies. The service was initiated by pharmacy owners and Estonian Pharmacies Association. ${ }^{62}$ In 2018, the vaccination rate increased up to $78 \%$ (about $10 \%$ due to the vaccination campaign at community pharmacies) compared to the previous years with vaccination rates in the elderly population, increased by $114 \%{ }^{53}$ These results indicate that community pharmacy vaccination programs have greatly contributed to overcoming a previous shortcoming in primary healthcare. In 2019, 17 pharmacies also started providing vaccination service against tick-borne encephalitis. ${ }^{63}$ Vaccination services in community pharmacies are currently offered by a qualified nurse or midwife, which are paid by patients. Pharmacists have an important role as advocates for vaccination services, but they do not receive direct remuneration for the service. ${ }^{53}$

Although initial results of community pharmacy vaccination programs have been widely successful and appreciated by patients, policy makers and other health care specialists remain skeptical. ${ }^{53}$ Community pharmacies have received unjust criticism mainly from GPs as if they have been hoarding vaccines, in shortage conditions for their own service. ${ }^{64}$ Another indicator of distrust towards community pharmacy vaccination services is the exclusion of pharmacies from COVID-19 vaccination programs by policy makers, mainly due to the fact that pharmacists currently do not have access to patient's health data. ${ }^{65}$

\section{Harm reduction}

In Estonia, HIV and narcotics use are serious concerns. Estonian National HIV Action Plan for 2017-2025 had proposed the engagement of community pharmacies in needle exchange, dispensing of naloxone and providing opioid replacement therapy. ${ }^{66}$ Engagement of pharmacists in harm reduction is one of the few examples of policy makers initiating integration of pharmacies into primary healthcare. However, pharmacy owners have shown lack of motivation to provide these services. By 2019, only one community pharmacy has engaged in the program. However, in just 8 months, the single participating pharmacy managed to hand out 10000 needles and had approximately 450 visits. ${ }^{67}$

\section{Smoking cessation}

In 2018-2019 the National Institute of Health Development of Estonia organized several training programs for pharmacists with the aim of engaging community pharmacies in providing a smoking cessation service. The service was piloted in early 2020 and included assessment of motivation and tobacco dependence, setting a quit date and individual cessation plan, recommending treatment, guidance on relapse prevention, and follow up. As a treatment for nicotine withdrawal symptoms, trained pharmacists could only recommend nicotine replacement therapy; for other treatment methods, patients were redirected to their GP. ${ }^{68}$ Despite initial plans, no national funding for the service followed; therefore, only a few pharmacies continued providing the service for free. Currently, community pharmacies participate in the public campaign Sigarexit to support tobacco-free lifestyle, by handing out booklets and drawing attention to health risks of cigarette smoking during consultations. ${ }^{69}$

\section{CONCLUSION}

Estonian healthcare system involves various parties: healthcare professionals, patients, government agencies, and policy makers. It is important to define shared interests among stakeholders to provide quality care to patients. Since regaining independence, Estonian pharmacy system has attempted to develop in parallel with the primary healthcare system, offering patients various services for both prevention and treatment of diseases. Accessibility of 
pharmacy services in terms of location and opening hours, professional competencies, and services could make community pharmacies an important part of healthcare. However there is a need for a vision for the role of community pharmacies in society. The tasks of pharmacists as healthcare professionals must be defined at a national level. The progress in pharmacy services has so far been achieved as a result of internal professional initiatives led by pharmacy and not by government. The best example is Community Pharmacy Service Quality Guidelines which support the standardization of traditional and the promotion of extended services. Flu vaccination, medication use review and smoking cessation are some of the services recently piloted in community pharmacies in
Estonia. Larger public interest, more involvement by the State, consolidation of the pharmacy sector to improve collaboration between different healthcare professionals can lead to successful integration into primary health care and potentially result in a positive impact on public health.

\section{CONFLICT OF INTEREST}

None.

\section{FUNDING}

None.

\section{References}

1. Nutt M. The Establishment and Restoration of Estonian Independence and the Development of Estonian Foreign Relations. https://vm.ee/sites/default/files/content-editors/web-static/439/Mart Nutt.pdf (accessed Jan 4, 2021).

2. Statistics Estonia. http://www.stat.ee (accessed Jan 4, 2021).

3. OECD. Demographic references, OECD Health Statistics. https://doi.org/10.1787/data-00547-en (accessed Jan 4, 2021).

4. 2020 Human Development Report. United Nations Development Programme. 2019. http://hdr.undp.org/sites/default/files/hdr2020.pdf (accessed Jan 4, 2021).

5. Health Insurance Fund. https://haigekassa.ee/en/people/health-insurance (accessed Jan 4, 2021).

6. OECD, Education Policy Outlook Estonia. 2016. http://www.oecd.org/estonia/Education-Policy-Outlook-Country-ProfileEstonia.pdf (accessed Jan 4, 2021).

7. Reynold, M. Welcome to E-stonia, the world's most digitally advanced society. https://www.wired.co.uk/article/digitalestonia (accessed Jan 4, 2021).

8. Ministry of Social Affairs. Analüüs tervishoiu rahastus vajab süsteemset muutust [Analysis of health care financing needs systemic change]. https://www.sm.ee/et/uudised/analuus-tervishoiu-rahastamine-vajab-susteemset-muutust (accessed Mar 23, 2021).

9. National Institute for Health Development. https://www.tai.ee (accessed Jan 4, 2021).

10. Ministry of Social Affairs. Rahvastiku Tervise Arengukava 2020-2030. https://www.sm.ee/et/rahvastiku-tervisearengukava-2020-2030 (accessed Jan 20, 2021).

11. Regions for Health Network. Overview of Estonian Healthcare. https://www.euro.who.int/ data/assets/pdf file/0005/373154/rhn-estonia-eng.pdf (accessed Jan 21, 2021 ).

12. Ministry of Social Affairs homepage. https://www.sm.ee/en (accessed Jan 4, 2021).

13. Estonian Health Insurance Fund Yearbook 2019. Estonian Health Insurance Fund. https://www.haigekassa.ee/en/organisation/annual-reports-0 (accessed Jan 21, 2021).

14. Hospitals Union. Healthcare in Estonia Liit. 2015. https://haiglateliit.ee/en/healthcare-in-estonia/ (accessed Jan 18, 2021).

15. Ministry of Social Affairs. https://www.sm.ee/et/esmatasand (accessed Jan 4, 2021).

16. Ministry of Social Affairs. Ravimite väljakirjutamise ja apteekidest väljastamise tingimused ja kord ning retsepti vorm,RT I, 05.01.2016, 6. https://www.riigiteataja.ee/akt/105012016006 (accessed Jan 19, 2021).

17. Health Services Organisation Act 01.01.2021. https://www.riigiteataja.ee/en/eli/ee/Riigikogu/act/522122020004/consolide (accessed Jan 8, 2021).

18. Kierkegaard P. (2013). E-prescription across Europe. Health Technol. 2013;3:205-219. https://doi.org/10.1007/s12553012-0037-0

19. e-Estonia. E-solutions in Healthcare. https://e-estonia.com/solutions/healthcare/ (accessed Jan 8, 2021).

20. Implementation of cross-border e-prescriptions: https://www.tehik.ee/fileadmin/tehik/docs/TEHIK uld/Piiriuelese digiretsepti teenus 18.01.2019.pdf (accessed Jan 8 , 2021).

21. Jaagus T. [Cross - border data exchange]. https://ekoolitus.cito.ee/file/EPALi konverentsi 0809 ettekanded/7 T\%C3\%B5nis\%20Jaagus.pdf (accessed Jan 8 , 2021).

22. Koppel A, Kahur K, Habicht T, et al. Estonia: Health system review. Health Systems in Transition. 2008;10(1):1-230.

23. Medicinal Product Act. RT I 2005, 2, 4. https://www.riigiteataja.ee/en/eli/ee/525112013005/consolide/current (accessed Jan 18, 2021).

24. Health Insurance Act. RT I 2002, 62, 377. https://www.riigiteataja.ee/en/eli/ee/529122016002/consolide/current (accessed Jan 18, 2021).

25. Med24. [Pharmacists wrote down the trends for the next ten years]. https://www.med24.ee/uudised/apteekrid-panid-kirja\%C3\%A4rgmise-k\%C3\%BCmne-aasta-arengusuunad (accessed Mar 23, 2021).

26. European Commission. A pharmaceutical strategy for Europe. https://ec.europa.eu/health/human-use/strategy en (accessed Jan 12, 2021). 
27. Mägi K, Lepaste M, Szkultecka-Dębek M. Drug Policy in Estonia. Value Health Reg Issues. 2018;16:1-4. https://doi.org/10.1016/j.vhri.2017.10.001

28. Estonian Health Insurance Fund. [Revaluation of medicines]. 2017 https://www.haigekassa.ee/partnerile/ravimid/ravimitejuurdehindlus (accessed Jan 20, 2021).

29. Ministry of Social Affairs. [Analysis of weighted average mark-ups on wholesale and retail sales of medicines.]. https://www.sm.ee/sites/default/files/ravimite kkjh2019 12.2020 1.pdf (accessed Jan 20, 2021).

30. Estonian Health Insurance Fund. Additional benefit for pharmaceuticals. https://www.haigekassa.ee/en/people/benefits/additional-benefit-pharmaceuticals (accessed Jan 20, 2021).

31. Ministry of Social Affairs. [Basics of Pharmaceutical Policies]. https://www.sm.ee/sites/default/files/contenteditors/eesmargid ja tegevused/Tervis/Ravimid/ravimipoliitika alused 2013.pdf (accessed Jan 20, 2021).

32. World Health Organization. Review of the Estonian Pharmaceutical Sector: Towards the development of a National Medicines Policy. https://www.euro.who.int/ data/assets/pdf file/0004/96448/E93049.pdf (accessed Jan 21, 2021).

33. Laius O. [Can a cheap drug be good?] https://pood.aripaev.ee/Product/DownloadProductResourceFile/1508 (accessed Jan 21, 2021).

34. World Health Organization Regional Office for Europe. Estonia: making medicines affordable and accessible for all. https://www.euro.who.int/en/countries/estonia/news/news/2019/9/estonia-making-medicines-affordable-and-accessiblefor-all (accessed Jan 28, 2021).

35. [Conditions and procedure for prescribing and dispensing medicines from pharmacies and the prescription form]. https://www.riigiteataja.ee/akt/106012021015?leiaKehtiv (accessed Jan 15, 2021).

36. State Agency of Medicines. Pharmacy statistics. https://sam.ee/apteegistatistika?group $=5$ (accessed Jan 5, 2021).

37. State Agency of Medicines. Activity Pharmacy License Search. https://rkav.sm.ee/rkav/faces/pages/tegevuslubaForm/tegevuslubaOtsing.jspx;jsessionid=DCDDAF2ADA3742B3B98252B 9951C4F01 (accessed Jan 5, 2021).

38. State Agency of Medicines. Online Pharmacies. https://ravimiamet.ee/en/node/7041 (accessed Jan 20, 2021).

39. Ministry of Social Affairs. The analysis of the weighted average mark-ups at pharmaceutical wholesale and retail. https://www.sm.ee/sites/default/files/contenteditors/eesmargid ja tegevused/Tervis/Ravimid/analuus ravimite keskm juurdehindlus 2012.pdf (accessed Jan 24, 2021).

40. Supreme Court. The Supreme Court repealed restrictions on the establishment of community pharmacies. https://www.riigikohus.ee/et/uudiste-arhiiv/riigikohus-tunnistas-apteekide-asutamispiirangud-kehtetuks (accessed Jan 15, 2021).

41. Ministry of Social Affairs. [Fact sheet: Pharmacy ownership Reform] https://www.sm.ee/sites/default/files/news-relatedfiles/faktileht apteegireform 2608.pdf (accessed Jan 15, 2021).

42. State Agency of Medicines. The State Agency of Medicines' overview of pharmacies in the light of the 2020 pharmacy reform and the extraordinary situation due to COVID-19. https://www.ravimiamet.ee/ravimiameti-\%C3\%BClevaadeapteekidest-2020-aasta-apteegireformi-ja-eriolukorra-valguses (accessed Jan 6, 2021).

43. Luik-Tamme I. Overview of the Estonian pharmacy market. https://www.tgsbaltic.com/en/publications/overview-of-theestonian-pharmacy-market (accessed Mar 20, 2020).

44. Supreme Court of Estonia. [Supreme Court: The State Agency of Medicines must verify whether the pharmacist has actual control over the pharmacy]. https://www.riigikohus.ee/et/uudiste-arhiiv/riigikohus-ravimiamet-peab-kontrollima-kasproviisoril-apteegi-ule-tegelik-voim (accessed Mar 23, 2021).

45. Volmer D, Sepp K, Raal A, et al. Pharmacy practice and education in Estonia. Pharmacy. 2019;7(3):87. https://doi.org/10.3390/pharmacy7030087

46. Health Board. Register for pharmacists and assistant pharmacists. http://mveeb.sm.ee/Apteekrid/ (accessed Jan 5, 2020).

47. Estonian Pharmacies Association. Community Pharmacy Service Quality Guidelines. 2016. https://www.ravimiamet.ee/sites/default/files/documents/publications/apteegiteenuse kvaliteedijuhis 2016/apteegiteenuse kvaliteedijuhis 2016.html (accessed Jan 20, 2021).

48. Sepp K, Koppel A, Volmer D. [Implementation of pharmacy service quality guidelines in Estonian general pharmacies 2014-19]. Apteek Täna. 2020;4: 83-94.

49. Apotheka. Smoking cessation campaign in community pharmacies. https://www.apotheka.ee/teenused/tubakastloobumine (accessed Mar 15, 2021).

50. National Institute for Health Development. Cardiovascular Prevention campaign for cardiovascular disease. https://tai.ee/et/koolitused-ja-sundmused/event/1146-sudamekuu (accessed Mar 15, 2021).

51. Apotheka. Pharmacists encouraging participation in screening program. https://www.apotheka.ee/terviseinfo/apteekridjulgustavad-inimesi-soeluuringutes-osalema/ (accessed Mar 15, 2021).

52. Tuula A, Randmäe L, Volmer D. [Evaluation of drug use - testing of a new additional service in Estonian genera pharmacies]. Perearst. 2020;155(3):18-21.

53. Sepp K, Kukk C, Cavaco A, Volmer D. How involvement of community pharmacies improves accessibility to and awareness about flu vaccination? - An example from Estonia. Expert Rev Vaccines. 2020;19(10):983-990. https://doi.org/10.1080/14760584.2020.1825949

54. Apotheka homepage. Extended pharmacy services in Apotheka pharmacies. https://www.apotheka.ee/teenused/ (accessed Jan 15 2021)

55. Benu homepage. Extended pharmacy services at BENU pharmacies. https://benutervisepunkt.ee/ (accessed Jan 15 2021)

56. Südameapteek homepage. Extended pharmacy services in Südameapteek. https://www.sudameapteek.ee/teenused/ (accessed Mar 17 2021) 
57. Valge-Rebane K, Sepp K. [Involvement of pharmacists in diabetes risk assessment of patients] Apteek Täna. 2021; 2:2229.

58. Tuula A, Šorina E, Jõhvik L, et al. [Investigation of the possibilities of applying the international classification for the evaluation of drug related problems of polypharmacy patients at community pharmacies in Estonia]. Aptek Täna. 2021;2 [in press].

59. University of Tartu. Clinical pharmacy e-learning programme. 2020. https://clinicalpharmacy.ut.ee/avaleht (accessed Jan 5 2021).

60. Volmer D, Tuula A, Randmäe L, et al. Medication use review at community pharmacies: an international pilot project. European Drug Utilisation Research Group Conference 2020. Szeged (Hungary), 4-7 March 2020,

61. Mereckiene J. European Centre for Disease Prevention and Control (ECDC) Technical Report, Seasonal influenza vaccination and antiviral use in EU/EEA Member States, https://www.ecdc.europa.eu/sites/portal/files/documents/Seasonal-influenza-antiviral-use-EU-EEA-Member-StatesDecember-2018 0.pdf (accessed Jan 15 2021).

62. Sepp K. [Vaccination flagship project - a successful pharmacy initiative]. Apteek Täna 2018, 1:11-14.

63. Eesti Proviisorapteekide Liit. [Get vaccinated at the pharmacy]. https://www.vaktsineeriapteegis.ee/et (accessed Jan 15 2021).

64. Eesti Rahvusringhääling. Paper: Pharmacies hoarding flu vaccines, will not sell to family doctors. https://news.err.ee/1143563/paper-pharmacies-hoarding-flu-vaccines-will-not-sell-to-family-doctors (accessed Jan 15 2021).

65. Eesti Rahvusringhääling. [Kiik, Lanno, Jaani and Vallikivi about the spread of virus in Estonia]. https://www.err.ee/1222765/video-kiik-lanno-jaani-ja-vallikivi-viiruse-levikust-eestis (accessed Jan 15 2021).

66. National HIV Action Plan 2017-2025. https://mv.ecuo.org/wpcontent/uploads/sites/4/2018/05/hiv riiklik tegevuskava 2017 2025.pdf (accessed Jan 5, 2021).

67. Kivimets K. [The harm reduction service has got off to a successful start in the Tartu Town Hall pharmacy.] Apteek Täna. 2020;3:20-21.

68. Saapar M. [The role of community pharmacy in smoking cessation.] Apteek Täna. 2019;3:18-19.

69. National Institute for Health Development. Sigarexit. https:www.tubakainfo.ee (accessed Jan 26, 2021). 